\title{
Pembentukan Sahabat 5 G (Galakan Gizi Gapai Generasi Golden) Pada Remaja di SMP Pangudi Luhur Kalibawang Kulonprogo
}

\author{
Paulinus Deny Krisnanto ${ }^{1 *}$, Cornelia Dede Yoshima Nekada ${ }^{2}$ \\ ${ }^{1,2}$ Universitas Respati Yogyakartau, Indonesia \\ paulinusdeny@gmail.com
}

\begin{abstract}
ABSTRAK
Remaja merupakan transisi dari masa kanak-kanak ke masa dewasa yang ditandai sejumlah perubahan biologis, kognitif dan emosional. Perubahan biologis yaitu pertambahan tinggi badan, perubahan hormonal dan kematangan seksual. Dukuh Boro memiliki sekolah setingkat sekolah menengah pertama yakni SMP Pangudi Luhur 1 Kalibawang yang berdiri sejak tahun 1955. SMP Pangudi Luhur 1 Kalibawang merupakan satu kompleks dengan panti asuhan Santa Maria. Kondisi perekonomian dan pola hidup sederhana menyebabkan para remaja ini tidak terlalu memperhatikan kondisi kesehatan dan gizi. Metode: Pelatihan dan pendampingan pembentukan Sahabat 5G (Galakkan Gizi Gapai Generasi Golden) yang meliputi kesehatan tentang gizi, kesehatan reproduksi, serta pelatihan dan pendampingan pembentukan Posyandu Remaja di SMP Pangudi Luhur Kalibawang yang dilakukan pada bulan Juni 2019. Hasil: Tingkat pengetahuan remaja tentang kesehatan reproduksi mengalami peningkatan dari skor 56, 6 menjadi 84,7. Sedangkan Tingkat pengetahuan tentang gizi seimbang didapatkan nilai 47,5 menjadi 82,6. Terbentuknya 20 remaja SMP Pangundi Luhur Kalibawang Kulonprogo menjadi Sahabat 5 G. Kesimpulan: Pendidikan kesehatan dapat meningkatkan pengetahuan dan telah terbentuknya Sahabat 5 G.
\end{abstract}

Kata Kunci: Sahabat 5 G, Remaja, Pendidikan Kesehatan

\section{PENDAHULUAN}

Remaja merupakan transisi dari masa kanak- kanak ke masa dewasa yang ditandai sejumlah perubahan biologis, kognitif dan emosional. Perubahan biologis yaitu pertambahan tinggi badan, perubahan hormonal dan kematangan seksual (Soejiningsih, 2014). Perubahan kognitif yang terjadi adalah meningkatnya berpikir abstrak, idealistik dan logis. Perubahan sosio emosional meliputi tuntutan untuk mencapai kemandirian, konflik dengan orang tua dan keinginan untuk meluangkan waktu bersama teman sebaya. Perubahan yang terjadi pada masa transisi ini membutuhkan asupan zat gizi yang optimal untuk mendukung pertumbuhan dan perkembangan remaja. Puncak pertumbuhan remaja 
putri terjadi pada usia 12 tahun dan remaja putra terjadi pada usia 14 tahun (Nelson, 1996 dan Almatsier, 2004)

Data sensus penduduk tahun 2010 menyatakan bahwa jumlah remaja usia 10-14 tahun menduduki jumlah penduduk terbanyak nomer dua di Indonesia setelah usia produktif 25-29 tahun. Data 33 provinsi di Indonesia menyebutkan bahwa Daerah Istimewa Yogyakarta merupakan salah satu provinsi dengan jumlah remaja terbanyak di Indonesia. Remaja di provinsi Daerah Istimewa Yogyakarta memiliki masalah gizi ganda berupa gizi kurang dan gizi lebih (Kemenkes, 2017). Masalah gizi lain pada remaja di Daerah Istimewa Yogyakarta ialah anemia pada remaja putri (Kemenkes, 2017 dan Indartati, 2014).

Daerah Istimewa Yogyakarta terletak di bagian tengah- selatan Pulau Jawa. Daerah Istimewa Yogyakarta secara administratif terdiri dari satu kota dan empat kabupaten. Kabupaten Kulon Progo merupakan salah satu dari empat kabupaten yang ada di Provinsi Daerah Istimewa Yogyakarta. Kabupaten Kulon Progo beribu kota di Wates dan terletak $30 \mathrm{~km}$ sebelah barat kota Yogyakarta dengan luas 586,28 $\mathrm{km}^{2}$. Wilayah Kabupaten Kulon Progo secara administratif terbagi menjadi 12 kecamatan, 87 desa dengan 917 dusun. Secara umum kondisi Kabupaten Kulon Progo adalah dataran rendah dengan dikelilingi perbukitan menoreh pada bagian utara. Perbukitan Menoreh ini meliputi Kecamatan Girimulyo, Kokap, Samigaluh dan Kalibawang. Topografi ini menempatkan keempat kecamatan ini sebagai daerah rawan bencana baik bencana banjir, tanah longsor, kekeringan bahkan gempa bumi (Dinkes Kulonprogo, 2015)

Desa Banjarasri merupakan wilayah administrasi di Kecamatan Kalibawang Kabupaten Kulon Progo Provinsi Daerah Istimewa Yogyakarta. Letak astronomis Desa

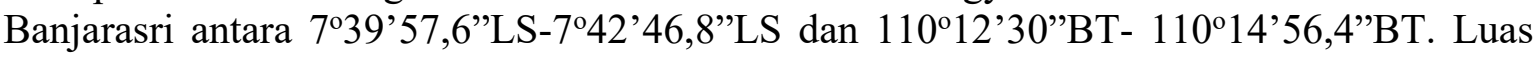
wilayah Desa Banjarasri 1.132,182 Ha yang terdiri dari tujuh belas dusun. Dusun Boro merupakan salah satu dusun yang berada di Desa Banjarasri Kulon Progo Yogyakarta. Dusun Boro berbatasan langsung dengan Dusun Boro Suci di sebelah utara, Dusun Kembang Sari di sebelah timur, Dusun Depok dan Dusun Sumber Sari di sebelah barat, Dusun Kalijeruk disebelah Selatan. Mata pencaharian utama di Dusun Boro sebagai petani dan buruh tani (Dinkes Kulonprogo, 2015)

Situasi derajat kesehatan masyarakat Kabupaten Kulon Progo sangat beragam. Sejak tahun 2014 semua kecamatan di Kabupaten Kulon Progo termasuk ke dalam kecamatan bebas rawan gizi meskipun cakupan balita bawah garis merah sebanyak $0.9 \%$. Secara nasional berdasarkan Riskesdas 2013, Daerah Istimewa Yogyakarta memiliki prevalensi pendek pada remaja usia 13-15 tahun lebih tinggi $(35,1 \%)$ dibandingkan prevalensi pendek remaja usia 5-12 tahun (30,7\%). Prevalensi anemia pada anak usia 5-14 tahun lebih besar daripada angka nasional (21.7\%) yakni sebesar 26.4\% dengan prosentase perempuan lebih banyak dibanding laki- laki (Dinkes Kulonprogo, 2015 dan Riskesdas 2013)

Dukuh Boro memiliki sekolah setingkat sekolah menengah pertama yakni SMP Pangudi Luhur 1 Kalibawang yang berdiri sejak tahun 1955. SMP Pangudi Luhur 1 Kalibawang merupakan satu kompleks dengan panti asuhan Santa Maria.Kondisi perekonomian dan pola hidup sederhana menyebabkan para remaja ini tidak terlalu memperhatikan kondisi kesehatan dan gizi.

Para remaja yang setingkat sekolah menengah pertama ini memiliki kemandirian dan kepedulian tinggi terhadap teman dan warga sekitar berdasarkan observasi yang dilakukan tim. Para remaja ini tidak segan untuk membantu sesuai dengan kapasitas masing- masing. 


\section{Journal of Community Engagement in Health}

http://jceh.org

ISSN: 2620-3758 (print); 2620-3766 (online)

https://doi.org/10.30994/jceh.v3i1.24

Vol.3 No.1. March 2020. Page.5-10

\section{PERMASALAHAN MITRA}

Remaja yang mengenyam pendidikan di SMP Pangudi Luhur 1 Kalibawang bertempat tinggal di sekitar sekolah atau di panti asuhan Santa Maria.Kondisi perekonomian dan pola hidup sederhana menyebabkan para remaja ini tidak terlalu memperhatikan kondisi kesehatan dan gizi. Permasalahan pada SMP Pangudi Luhur 1 Kalibawang adalah kurangnya pengetahuan kesehatan dan gizi para remaja.

\section{METODE PELAKSANAAN}

Metode yang digunakan dalam kegiatan ini yaitu metode participatory action research dimana mitra pertama dan kedua beserta tim UNRIYO secara bersama-sama dilibatkan dalam penentuan jenis kegiatan dan pelaksanaan kegiatan di lapangan. Pelatihan dan pendampingan pembentukan Sahabat 5G (Galakkan Gizi Gapai Generasi Golden) yang meliputi kesehatan tentang gizi, kesehatan reproduksi, serta pelatihan dan pendampingan pembentukan Posyandu Remaja di SMP Pangudi Luhur 1 Kalibawang yang dilakukan pada bulan Juni 2019.

\section{HASIL}

1. Pendidikan Kesehatan Reproduksi

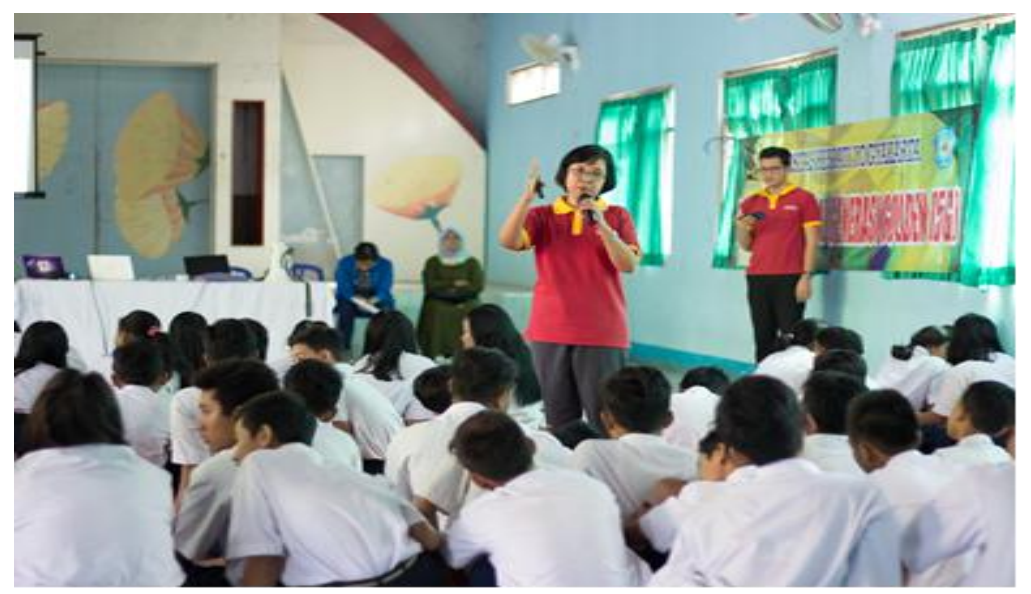

2. Penyuluhan terkait dengan gizi

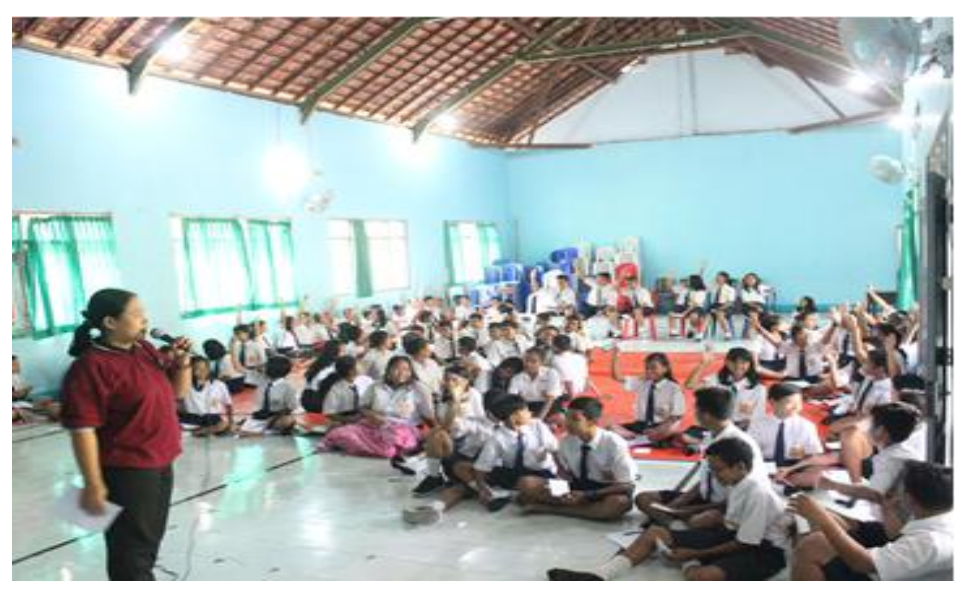




\section{Journal of Community Engagement in Health}

http://jceh.org

ISSN: 2620-3758 (print); 2620-3766 (online)

https://doi.org/10.30994/jceh.v3i1.24

Vol.3 No.1. March 2020. Page.5-10

3. Pelatihan terkait dengan statuz gizi

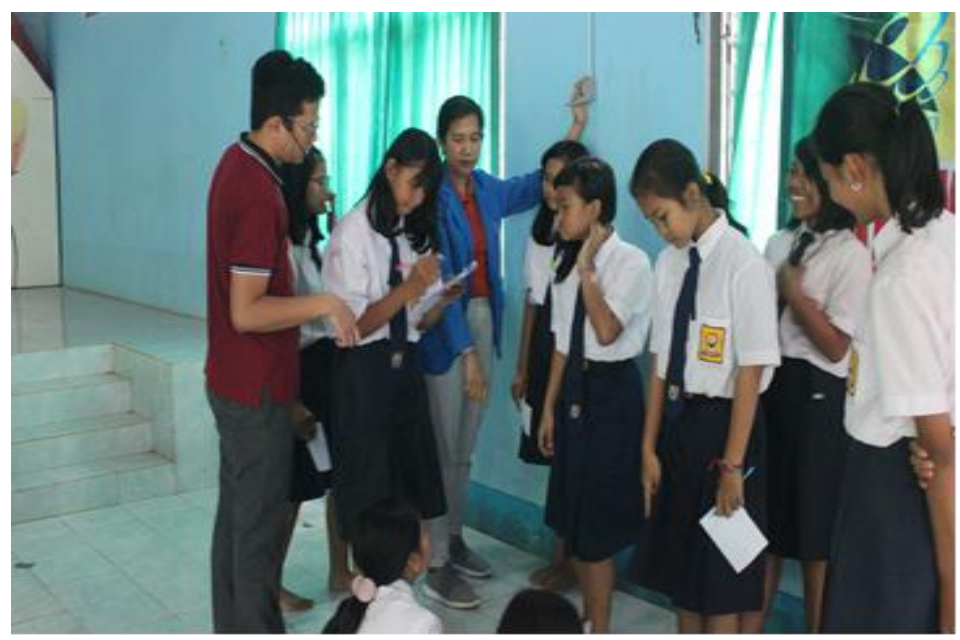

4. Pembentukan Sahabat 5 G

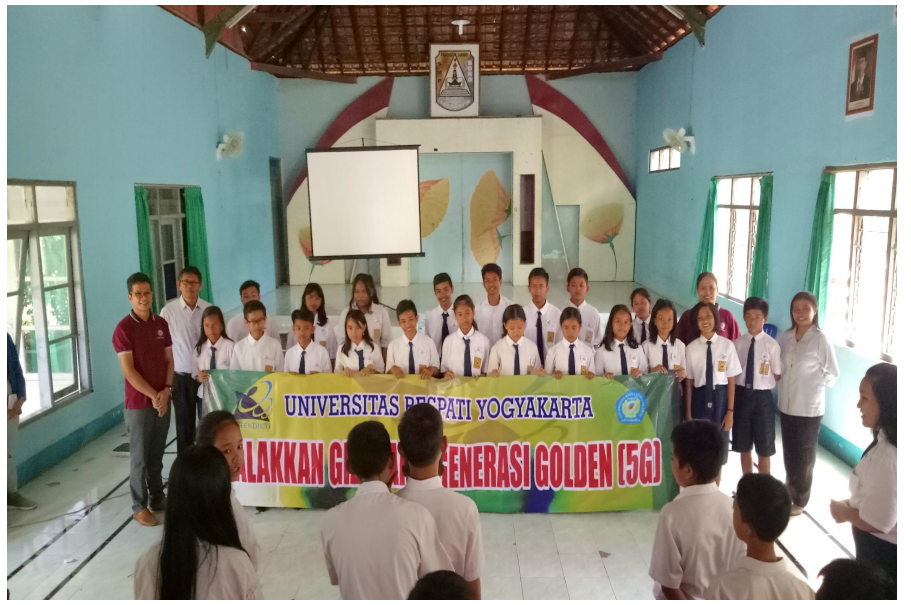

PEMBAHASAN

Berdasarkan hasil pengabdian yang dilakukan didapatkan bahwa tingkat pengetahuan remaja tentang kesehatan reproduksi mengalami peningkatan dari skor 56,6 menjadi 84,7. Sedangkan Tingkat pengetahuan tentang gizi seimbang didapatkan nilai 47,5 menjadi 82,6. Berdasarkan hasil ini dapat disimpulkan bahwa pendidikan kesehatan akan meningkatkan pengetahuan remaja terkait dengan kesehatan reproduksi dan gizi seimbang. Belum 1990 dalam (Nursalam, 2008) menyatakan bahwa salah satu faktor yang mempengaruhi status kesehatan adalah perilaku kesehatan. Perubahan perilaku menuju ke arah hidup yang kondusif untuk kesehatan dapat dilakukan melalui pendidikan kesehatan. Pendidikan kesehatan merupakan suatu proses yang direncanakan untuk menciptakan peluang bagi individu untuk senantiasa belajar memperbaiki kesadaran serta meningkatkan pengetahuan dan ketrampilan demi kepentingan kesehatannya. Pendidikan kesehatan hendaknya diformulasikan dengan tujuan yang akan dicapai agar pelaksanaannya mempunyai arah yang jelas. Tujuan spesifik dari pendidikan kesehatan yaitu perubahan pengetahuan, sikap atau praktik/ketrampilan untuk meningkatkan pengetahuan.

Notoatmojo (2012) menyatakan bahwa pendidikan kesehatan dalam jangka waktu pendek dapat menghasilkan perubahan dan peningkatan pengetahuan individu, kelompok 
dan masyarakat. Untuk meningkatkan pengetahuan seseorang maka bisa dilakukan promosi kesehatan salah santunya adalah pemberian materi dimana dalam memberikan materi bisa menggunakan lebih dari satu indra. Oleh karena itu dalam memberikan pendidikan kesehatan dapat menggunakan tehnik komunikasi dengan 2 cara diantaranya adalah penyuluhan langsung (penyuluh langsung berhadapan atau bertatap muka dengan sasaran: pertemuan di balai desa, pertemuan di posyandu, pertemuan diskusi, ceramah dll) dan penyuluhan tidak langsung (penyuluh tidak berhadapan langsung dengan sasaran tetapi menyampaikan pesan dengan menggunakan media diantaranya adalah pertunjukkan film, poster, leaflet, slide, foto).

Hal ini sejalan dengan penelitian Siti (2012) yang menyatakan bahwa pendidikan kesehatan dengan metode ceramah, diskusi dan tanya jawab dapat meningkatkan pengetahuan gizi pada anak remaja. Penelitian Nuryanto et al (2015) yang menyatakan bahwa pendidikan kesehatan dengan metode penyuluhan dapat meningkatkan pengetahuan anak tentang gizi seimbang. Dwi (2014) juga menyatakan bahwa pendidikan kesehatan metode ceramah dan power point terkait reproduksi dapat secara signifikan meningkatkan pengetahuan remaja tentang kesehatan reproduksi.

Penggunaan audiovisual dengan menampilkan materi berupa gambar yang ditampilkan dalam slide akan memnuat responden menjadi tertarik untuk melihat dan membaca materi sehingga dapat membantu meningkatkan pengetahuan (Notoadmojo, 2012). Berdasarkan data diatas dapat disimpulkan bahwa pendidikan kesehatan dapat meningkatkan pengetahuan remaja baik terkait reproduksi dan gizi seimbang.

Pengabdian yang dilakukan tidak sampai terkait penyuluhan tentang reproduksi dan gizi seimbang tetapi juga melakukan pelatihan kepada remaja sebanyak 20 orang yang ditunjuk untuk menjadi Sahabat 5G (Galakkan Gizi Gapai Generasi Golden) yang bertugas untuk melakukan pengukuran status gizi pada anak remaja. Sebelum pelaksanaan 20 remaja ini dilatih terlebih dahulu terkait dengan cara mengukur tinggi badan, berat badan dan mengintepretasikan status gizi. Hasil yang didapatkan 20 remaja yang ditunjuk telah bisa melakukan kegiatan pengukuran status gizi.

\section{KESIMPULAN}

Berdasarkan penelitian yang telah dilakukan diperoleh hasil dimana Pendidikan kesehatan tentang kesehatan reproduksi dapat meningkatkan pengetahuan pada remaja di SMP Kalibawang Kulonprogo dan dapat meningkatkan pengetahuan remaja di SMP Kalibawang. Dan dari penelitian ini telah terbentuk Sahabat 5 G (Galakkan Gizi Gapai Generasi Golden) untuk meningkatkan promosi kesehatan pada remaja.

\section{DAFTAR PUSTAKA}

Almatsier S. Prinsip Dasar Ilmu Gizi. Jakarta: Gramedia Pustaka Utama. 2004

Badan Penelitian dan Pengembangan Kesehatan Kemenkes RI. Riset Kesehatan Dasar (Riskesdas) 2013. Jakarta: Badan Penelitian dan Pengembangan Kesehatan Kementerian Kesehatan RI; 2013.

Dinas Kesehatan Kabupaten Kulon Progo. Profil kesehatan kabupaten kulon progo tahun 2015 (Data 2014). Yogyakarta: Dinkes Kabupaten Kulon Progo; 2015

Dwi, S. Efektivitas Pendidikan Kesehatan Reproduksi terhadap peningkatan Pengetahuan Remaja di SMK Islam Wijaya Kusuma Jakarta Selatan. Jurnal Keperawatan Soedirman (The Soedirman Journal of Nursing). Volume 9 No 2. 2014

Indartanti D dan Kartini A. Hubungan status gizi dengan kejadian anemia pada remaja putri. Journal of Nutrition College. 2014; 3(2): 33-9. 
Kementerian Kesehatan RI. Profil kesehatan Indonesia tahun 2016. Jakarta: Kementerian Kesehatan RI; 2017.

Nelson. Ilmu Kesehatan Anak volume 1. (diterjemahkan oleh: Samik Wahab). Jakarta: EGC. 1996.

Notoadmojo. Promosi Kesehatan dan Perilaku Kesehatan. Rineka Cipta. 2012

Nursalam \& Fery Efendi. Pendidikan Dalam Keperawatan. Salemba Medika. 2008

Siti, Z. Efektivitas Pendidikan Gizi dengan Media Booklet Terhadap Pengetahuan Gizi Anak SD. Jurnal Kesehatan Masyarakat (KESMAS) 7 (2) 2012 (121-128).

Soetjiningsih. Tumbuh Kembang Remaja dan Permasalahannya. Jakarta: Sagung Seto. 2004. 